\title{
The Effect of Empowerment, Work Environment, and Career Development on Employees Performance with Work Motivation as The Intervening Variable in The Government of Aceh - Indonesia
}

\author{
Em Yusuf Iis ${ }^{\mathrm{a}, *}$, Wahyuddin $^{\mathrm{a}}, \&$ Armanu Thoyib ${ }^{\mathrm{b}}$ \\ ${ }^{a}$ Faculty of Economics and Business, Malikussaleh University, Indonesia \\ ${ }^{b}$ Postgraduate Studies, Faculty of Economics, Universitas Brawijaya, Malang, Indonesia
}

\begin{abstract}
This study aimed to examine the effect of employee empowerment, work environment, and career development on the performance of Aceh Government employees. Data were obtained by distributing questionnaires to 150 employees. Data analysis method was Structural Equation Modeling (SEM). The results showed that employee empowerment, work environment, and employee career development affected work motivation and employee performance significantly. In addition, employee empowerment and work motivation have a direct and significant influence on employee performance, and career development and work environment also have a direct effect on performance. Work motivation partially mediates the influence of employee empowerment, work environment, career development on performance. The Government of Aceh is expected to improve career development in order to create a conducive work environment to improve the performance of Aceh Government employees.
\end{abstract}

Keywords: Empowerment; environment; career development; motivation; employee performance.

\section{Introduction}

Public organizations and employee performance have remained in the spotlight of human resource management experts. Newstrom and Davis (2002), state that the performance of employee is influenced by the interaction between ability and motivation. This ability is formed by the interaction between knowledge and expertise, while motivation is formed by the interaction between attitudes and situations. Priyadharshany (2015) and Armstrong, (2016) say that the performance of employee is influenced by personal factors, work system factors, and internal and external factors. While Ulrich et al, (2012) state that the organizational performance is influenced by the individual performance in each organization. Ricardo and Wade (2001) mention that factors that influence performance are individual behavior, education and training, concepts and instruments, and management development and training.

Human resources owned by the Aceh government are crucial for the realization of organizational goals. Human resources do not only act out as the objects that must always get the attention and protection of the organization but also at the same time play a role as a subject that can determine the progress of the organization. To be able to realize these functions, human resources need to be directed, fostered, and guided in order to carry out their functions in accordance with the goals of the organization. As for getting performance, there needs to be an effort to work motivation, empowerment, career development, and utilization of a comfortable work environment in order to improve performance to be very important to support the improvement of the performance of its employees. Based on the observations and interviews with several leaders of the Aceh work unit, it can be stated that the low motivation of Acehnese employees to work is a major factor in the low performance of employees in the Aceh government. Each of

\footnotetext{
* Corresponding author.

E-mail address: xxxx@xxxxxx.edu (First Author)
} 
Aceh government work unit does not have a section yet that deals with employee development including the provision of counseling institutions for employee career development, except in the Personnel, Education and Training Agency which manages career development and empowerment of all employees within the Aceh government.

The empowerment of employees as motivational about self-fulfillment of individuals in the form of work (meaning), enhancement competence, determination of self-attitudes, and influence on work (Rowlinson, 2007). (Daily, Bishop, \& Massoud, 2012). Yi Li, (2015) state that Psychological employee empowerment consists of intrinsic and extrinsic motivation and is closely related to performance. Empowerment is the efficiency and effectiveness of the organization, through a comprehensive analysis of organizational competencies and management, Tutar, (2011) (Thomas \& Velthouse, 1990), Prahalad, (1993) Cakiroglu (2011). Their research on the effect of empowerment on work motivation shows the relationship. The empowerment of employees can be concluded as an activity to provide an integrated process model, Sharif (2013), Quigley and Tymon (2006). These results provide a comprehensive integrated process model. The empirial findings show that six components of intrinsic motivation for career management and career success are needed to improve performance. Also, extrinsically, motivational is as a psychological and motivational aspect of the relationship between intrinsic motivation and has the implications for the intrinsic motivation so that the work environment can guide management development.

The organizational management system has something to do with the work environment, Matthews et. al, (2002). Ortega et al, (2006), Renah \& Setyadi, (2014), the results show that the organizational culture, work environment, and good value of motivation have a significant relationship with performance. Malik et al, (2011), a non-physical work environment is very important in an organization where the non-physical work environment can unwittingly affect employee performance. Ortega, (2006), leadership strategies relate to the environment and innovation differentiation strategies relates to structure, internal and external adjustments. While Imran (2012), Kayabasa (2015), Mutlub (2015), Jayaweera (2015), claim that the results also show a significant relationship between work motivation and work performance. Gunaseelan et al, (2013), provides a theoretical contribution by developing models relating to the work environment and employee performance.

Empowerment is the efficiency and effectiveness of the organization, Khan et al, (2013). There are several studies that explain the direct relationship between employee empowerment of employee performance. For example, Faerman et al, (2010), Sharif (2013), Zeeshan et al, (2013), find that the better employee empowerment, the more employee performance increases. In addition, there are several contradictory studies of Sharif (2013), the strategy of creating competitiveness of employees. Manuel (1993), Ashraf et al, (2013), this indicates that there are mediating variables linking the empowerment to the employee performance.

Kariuki \& Murimi, (2015), (Yu \& Lee, 2015) describes career development is a long-term process to improve employee abilities and motivation so that they can become the members of organizations that have the values studies to explain the direct relationship between career development and employee performance. In addition, there are several contradictory studies (Oduma, Caroline and Were, 2014), Duclos et al, (2012), Schmid et al, (2017), Caroline (2014) which indicate that there are mediating variables that link career development to the performance employee.

Based on the opinions above, it can be concluded that there are still differences in the opinions of experts about the factors that influence performance. In addition, there are still differences in the views of experts regarding the theory that underly the empowerment of individual performance in an organization. Western experts such as Armstrong (2015), Ulrich (2012) and Ricardo Khan (2013) and Mckinesy (2014), focus more on individual internal factors as the main factors that influence performance. While experts like Bernardin (2013), Rampersad (2006), Prahalad (2006), they focus more on external factors as variables that affect individual performance.

Empirically, previous studies have examined the effects of empowerment which include work motivation, work environment and career development on performance, as practiced by Sharif, Ashraf, \& Khan, (2013). Their findings indicate that empowerment, work life policies, training and extra role behavior (OCB) have a significant effect on performance. Next, Tutar et al, (2011), empowerment has a significant effect on employee performance. The same results are also found by Meyerson \& Dewettinck, (2012). Nzuve \& Bakari, (2012) and Quigley \& Jr, (2006), empowerment has a positive effect. Furthermore, Carrolin \& Were (2014) find that empowerment and quality of work life, training, and career development play an important role in improving employee performance. 
Based on the empirical description above, it can be concluded that the findings of previous studies are still not consistent and still different. Some studies have found a positive and significant influence on work motivation, work environment, career development and talent on performance. Meanwhile, some of the other results reveal that there are differences in the direction of the relationship and the level of significance of the influence between work motivation, work environment, and career development on performance. As an important element in improving their performance. They also implement a restructuring strategy which is often referred to as downsizing or delayering, in which the practice reduces the number of workers, work units or divisions or reduces the level of position in the organizational structure of the company. The reduction of company staff is needed for efficiency and effectiveness, David (1997).

\section{The formulation of the problem}

There are some problem formulation in this study. They are 1) How is the influence of empowerment, work environment, career development on employee motivation in the Government of Aceh, 2) How is the influence of empowerment, work environment, Career Development on employee performance in the Government of Aceh, 3). How does motivation influence the performance of employees in the Government of Aceh. 4) Does motivation mediate between empowerment, work environment, Career Development and employee performance in the Government of Aceh.

The purposes of this research are to examine 1) the influence of empowerment, work environment, career development on the motivation of employees in the Government of Aceh, 2) the influence of empowerment, work environment, career Development on the employee performance in the Government of Aceh. 3) the effect of motivation on employee performance. 4) the mediation effect of Motivation mediates between empowerment, work environment, Career Development and the performance of the employee in the Government of Aceh.

\section{Literature Review}

\subsection{Empowerment}

The empowerment of employees is essentially a potential governance process and optimization of its utilization from each individual employee, in the context of career coaching and improvement of organizational performance. Empowerment is a motivational concept of self-fulfillment which is indicated by the enhancement of motivation of individual work in the form of meaning, competence, self-determination, and impact. Spreitzer, (1995). The objectives of empowerment of employees is to improve the efficiency and effectiveness of the organization through a comprehensive process of analysis of the competence and systemic management of the organization. Al-sulaiti, (2015) argues that the concept relates to several opinions above. There are 6 employee empowerment indicators taken based on Khan's (2013) opinion, namely: 1) Desire, 2) Trust, 3) Confident 4) Credibility. 5) Accountability and 6) Communication.

\subsection{Career development}

Career development is an issue in human resource research, and career management is a series of activities in attracting, developing and maintaining high-potential employees at all levels to achieve the objective of organizational strategic objectives. Empirically there are several previous studies that examine the effect of career development on performance, for example Orduma research, (2014) Ming, (2015), career management practices or career development have a significant effect on employee performance. The relationship between employees in the work environment is still not harmonious. The authority that has been given is still less awareness by the employees so that they sometimes do not give decisions that are their rights. In the ranks of the Aceh government, there is already a standard, and organizational procedure for employees in accordance with their respective fields of duty.

The limited position of the structure is one of the causes of the slow progress of regional employee career development although their superiors support every policy set by their organization. Limited and not fully promoted promotion by the organization is an obstacle to the career development, Ming-Chu's, and Meng-Hsiu Lee (2015). 
Each of Aceh government work unit does not have a section yet that deals with the development of employee including the provision of counseling institutions for employee career development except in the Aceh Personnel, Education and Training Agency which manages the career development of all employees within the Aceh government.

In addition, a research conducted by Peter \& Dabale, (2014) find that career development and employee motivation shows a positive and significant relationship to the employee performance. Allen, Day, \& Allen, (2016). The indicators of career development in this study are taken based on the opinion of Veithzal (2009), which consisted of 6 indicators consisting of career choices, job opportunities (Mid Career), career support, career enhancement, the willingness of the leader to promote, and leadership concern.

\subsection{Work Environment}

Work environment is a circumstance where employees or workers do their daily work (Mardiana, 2005). A conducive work environment provides a sense of security and allows employees to work optimally. The work environment can affect employee emotions. The work environment includes work relationships that are formed between fellow employees and work relations between subordinates and superiors as well as the physical environment in which employees work. The physical work environment in Aceh government organizations is generally good, but not fully utilized yet by existing employees to support the work performance. The existing work environment situation has not provided work comfort for employees. Kale \& Mazaheri, (2014). The work environment is also an important factor that influences employee performance, this is consistent with the research conducted by Jayaweera, (2015), the work environment and work performance have a significant effect on the employee performance mediated by work motivation in hotels in Bristol England.

Furthermore, Imran et al, (2012) indicate that transformational leadership and work environment have a significant effect on the employee performance in the Pakistani economic manufacturing sector. While other studies are Imran et al, (2015), Rashdi et al, (2014), Shahzadi et al, (2014), Malik, et al, (2011) and Malik et al (2011) still find differences in the level of significance and direction of influence. In this study, there are 6 indicators of work environment based on the opinion of Herberg in Luthans (2003) which consists of working conditions, work safety and security, workplace conditions, status, organizational procedures, quality of technical supervision from relationships between peers, superiors, and subordinates.

\subsection{Motivation}

Motivation is a process of psychological encouragement of individual needs as a basic process comprehensively based on competitiveness according to perception and personality. Luthans, (2012) asserts that motivation is a process to generate and encourage behavior and performance. It means that motivation is a process of stimulating someone in carrying out a task in order to determine the intensity, direction, and individual provisions in the effort to achieve performance. In addition, employee motivation is also an important factor that influences employee performance. This is consistent with the research conducted by Ayobami (2013), Khanam et al, (2014), Muogbo (2013), Woo (2014). Dobre, (2013), Mondy (2008) which claim that there is a positive and significant influence of work motivation on employee performance. Indicators of work motivation used in this study are in accordance with the opinion of Robbins (2007). They consist of aggressive, creative, quality, discipline, capable, high work initiatives, willingness to succeed, persistent and skillful, and dare to accept challenges.

\subsection{Performance}

The performance of employees is influenced by personal factors, work systems, and internal and external factors (Priyadharshany, 2015), Armstrong (2015). Bastian, (2001), the performance of time equality, the level of achievement of results on the implementation of certain tasks. In this case, it includes individual performance, group performance, the organizational performance which are influenced by internal and external factors. According to Furtwengler (2002) performance can be seen in terms of speed, quality, service, and value which means that the speed 
in the work process that has reliable quality, good service and value is seen from the achievement of employee performance can affect organizational performance.

Gomes (2003) uses eight indicators of employee performance, namely: 1) Work Quantity which means the amount of work carried out by Aceh Government employees within a specified time period. 2) Quality of work which means the work quality achieved by employees of the Government of Aceh based on the conditions of conformity and readiness. 3) Creativeness which means the authenticity of ideas raised by Aceh Government employees and actions to resolve problems. 4) Cooperation which means the willingness of the Aceh Government employees to work together with other fellow members of the organization. 5) Dependability which means that the awareness and trustworthiness by the Aceh Government employees in terms of attendance and completing work. 6) Initiative which means the spirit of the initiative by Aceh Government employees to carry out new tasks and in enlarging their responsibilities. 7) Job knowledge, namely the breadth of knowledge about work and skills. 8) Personal qualities, which involve personality, leadership, hospitality and personal integrity.

\section{Methods}

This is a quantitative research and uses a questionnaire as a tool to retrieve data and use the modified Linkert scale 1-5. The population in this study are all employees of the Aceh Government Planning Agency and the number of samples selected using the Census method is 150 employees. The analysis technique used is the Structural Equation Model (SEM) with the help of SPSS 16.0 and Amos 21.0. The validity test of the instrument is conducted using Confirmatory Factor Analysis (CFA) of each construct by looking at the Loading Factor value of each indicator. The results of each statement item have a value of $>0.6$. The reliability test uses the following formula:

$$
\text { Construct Reliability }=\frac{\left(\sum \text { std.loading }\right)^{2}}{\left(\sum \text { std.loading }\right)^{2}+\sum_{e i}}
$$

While the extract variants can be calculated using the following formula:

$$
\text { Variance Extracted }=\frac{\sum \text { std.loading }}{2}
$$

\section{Result and Discussions}

The results of the full model 1 analysis (initial model) using SEM analysis are in Figure 1. The calculation results of the goodness of fit index show that only two GFI and GFI criteria that have met the criteria from the eight evaluated criteria.

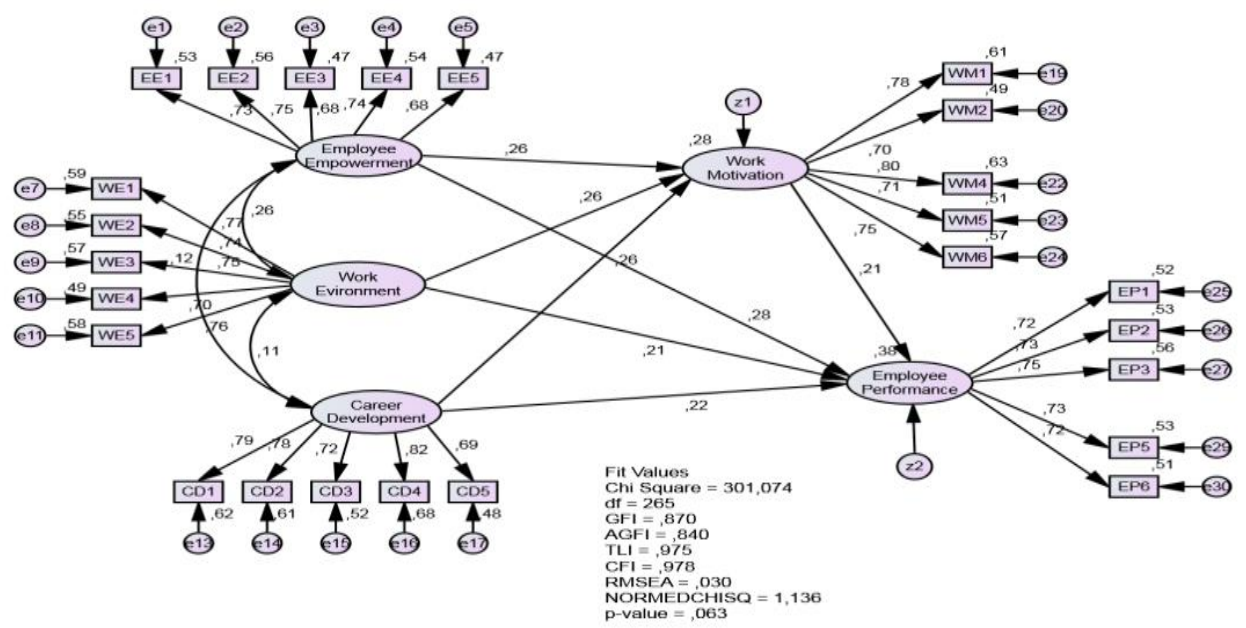

Fig. 1. Full Model Before Modification 
Table 1. Goodness of fit Indexs for Full Model Before Modification

\begin{tabular}{cccc}
\hline Goodness of fit Index & Cut-off Value & Analysis Results & Model Evaluation \\
\hline$\chi^{2}$ Chi-Square Statistik & Low value is expected & 301.074 & Good \\
Probability & $\geq 0,05$ & 0.063 & Good \\
CMIN/DF & $\leq 2.00$ & 265 & Marginal \\
GFI & $\geq 0.90$ & 0.870 & Marginal \\
AGFI & $\geq 0.90$ & 0.840 & Marginal \\
TLI & $\geq 0.95$ & 0.975 & Good \\
CFI & $\geq 0.95$ & 0.978 & Good \\
RMSEA & $\leq 0.08$ & 0.030 & Good \\
\hline
\end{tabular}

The results of the analysis of goodness of fit show that the overall evaluation of the model has met the specified criteria, except CMIN/DF, GFI, and AGFI which are still marginal. To improve the value of goodness of fit, modifications need to be done by connecting the errors suggested by Amos in the modification index (Ghozali, 2013). Figure 2 is a full image of the research model that has been modified.

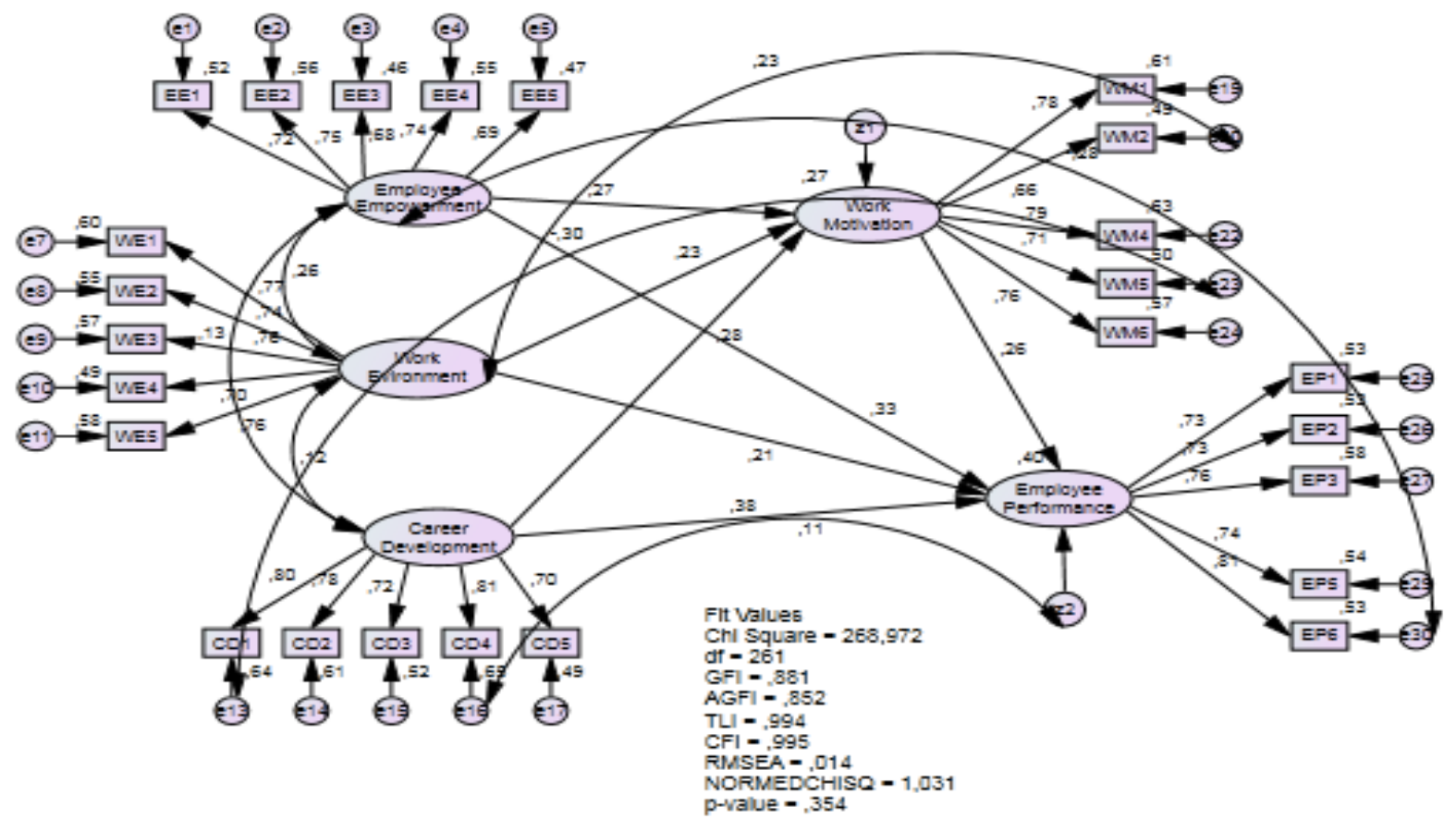

Fig. 2. Full Model After Modification

Tabel 2. Goodness of fit Indexs for Full Model after Modification

\begin{tabular}{lccc}
\hline \multicolumn{1}{c}{ Goodness of Fit Index } & Cut-off Value & Analysis Results & Model Evaluation \\
\hline$\chi^{2}$ Chi-Square Statistics & Expected to be low & 268,972 & Good \\
Probability & $>0,05$ & 0.354 & Good \\
CMIN/DF & $<2.00$ & 261 & Good \\
GFI & $>0.90$ & 0.881 & Marginal \\
AGFI & $>0.90$ & 0.852 & Marginal \\
TLI & $>0.95$ & 0.994 & Good \\
\hline
\end{tabular}




\begin{tabular}{lccc}
\hline \multicolumn{1}{c}{ Goodness of Fit Index } & Cut-off Value & Analysis Results & Model Evaluation \\
\hline CFI & $>0.95$ & 0.995 & Good \\
RMSEA & $<0.08$ & 0.014 & Good \\
\hline
\end{tabular}

The results of the goodness of fit analysis after modifying all criteria, the set values are better than before, except the GFI and AGFI values are still marginal. Thus the overall model is fit. To see the influence of the oxygen variables (empowerment, work environment, Career Development) on the intervening variable (Motivation) and endogenous variables (employee performance) are shown in Table 3.

Table 3. The Effect of Exogenous Variables on Endogenous Variables

\begin{tabular}{lllrrrr}
\hline & Latent & & Estimate & S.E. & C.R. & P \\
\hline Work Motivation & $<---$ & Work Evironment & .290 & .099 & 2.923 & .003 \\
Work_Motivation & $<--$ & Employee_Empowerment &, 228 &, 099 & 2,290 &, 022 \\
Work Motivation & $<---$ & Career Development &, 269 &, 090 & 2,999 &, 003 \\
Employee_Performance & $<---$ & Work_Evironment &, 186 &, 090 & 2,068 &, 039 \\
Employee Performance & $<--$ & Career Development &, 201 &, 082 & 2,448 &, 014 \\
Employee Performance & $<---$ & Employee Empowerment &, 311 &, 094 & 3,305 & $* * *$ \\
Employee Performance & $<---$ & Work Motivation &, 208 &, 090 & 2,304 &, 021 \\
\hline
\end{tabular}

The results of data analysis as shown in Table 3 can be known that all the exogenous variables (empowerment, work environment, and Career Development) have a significant direct influence on employee motivation and performance, and motivation has a significant effect on employee performance.

\section{Mediation Effect Tests}

To see the mediation effect, the amount of direct effects, indirect effects, and total effects must be seen. Based on the tests using Amos. 21.0, it can be obtained the results as in Table 4.

Tabel 4. Standardized Direct, Indirect \& Total Effects

\begin{tabular}{lccccc}
\hline & Career & Employee & Work & Work & Employee \\
\hline Direct Effects & & & & & \\
Work Motivation & 0,262 & 0,264 & 0,264 & 0 & 0 \\
Employee Performance & 0,221 & 0,284 & 0,210 & 0,214 & 0 \\
Indirect Effects & & & & & \\
Work Motivation & 0 & 0 & 0 & 0 & 0 \\
Employee Performance & 0,056 & 0,057 & 0,057 & 0 & 0 \\
Total Effects & & & & & \\
Work Motivation & 0,262 & 0,264 & 0,264 & 0 & 0 \\
Employee Performance & 0,277 & 0,34 & 0,266 & 0,214 & 0 \\
\hline
\end{tabular}

The results of intervening effect test on the relationship of empowerment and employee performance mediated by motivation is displayed in Figure 3.

Figure 3 show that the Coefficients of Path A, path B, and path C are significant but path $\mathrm{C}$ is insignificant. So, it concludes that there is a relationship of motivation which fully mediates between empowerment and employee performance at the Aceh Government Planning Agency. The intervening effect test results in the relationship between the work environment and employee performance mediated by Motivation is displayed in Figure 4. 


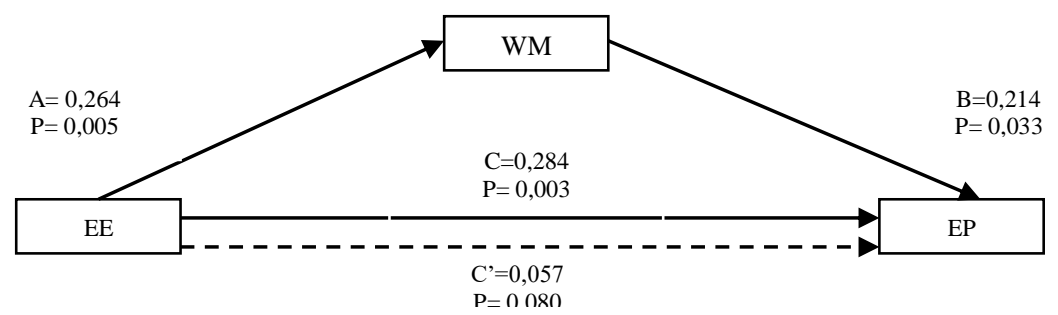

Fig. 3. Results of intervening effect test on the relationship of empowerment and employee performance mediated by motivation

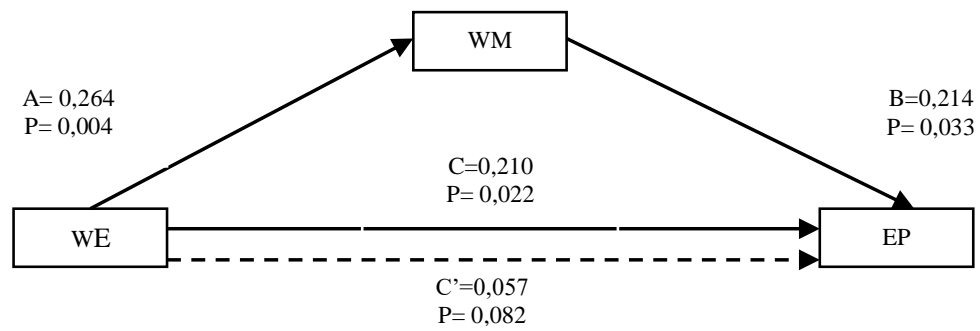

Fig. 4. The intervening effect test results in the relationship between the work environment and employee performance mediated by motivation

Figure 4 reveal that the coefficients of path $\mathrm{A}$, path $\mathrm{B}$, and path $\mathrm{C}$, are significant but path $\mathrm{C}$ is insignificant. Therefore, it concludes that there is a relationship of full mediation or Motivation fully mediates between the work environment and employee performance at the Aceh Government Planning Agency. Intervening effect tests results of Career Development with employee performance are mediated by Motivation which is displayed in Figure 5.

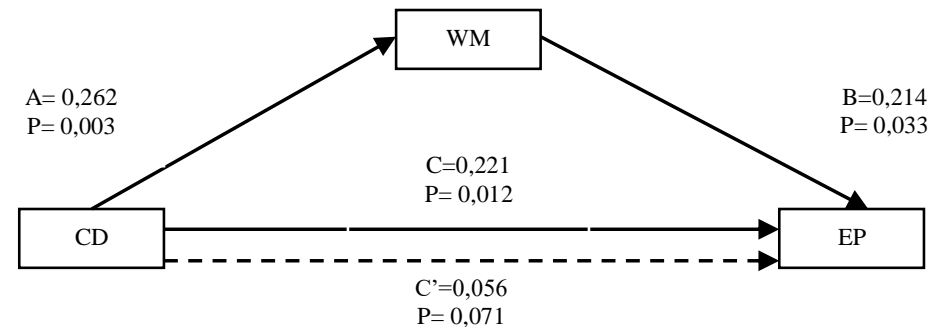

Fig. 5. Intervening effect tests results of career development with employee performance are mediated by motivation

Figure 5 explains that the coefficients of path $\mathrm{A}$, path $\mathrm{B}$, and path $\mathrm{C}$ are significant but the value of path $\mathrm{C}$ is insignificant so that it can be claimed that there is a full mediation relationship or it can be stated that Motivation fully mediates between Career Development and employee performance at the Aceh Government Planning Agency.

Tabel 5. The hypothesis test

\begin{tabular}{lccccc}
\hline \multicolumn{1}{c}{ Hypotesis Statements } & $\begin{array}{c}\text { Estimate } \\
\text { Std. }\end{array}$ & S.E. & CR & P & Conclussion \\
\hline $\begin{array}{l}\text { Empowerment has a positive and significant effect on } \\
\text { work motivation }\end{array}$ & 0,264 & 0,099 & 2,290 & 0,022 & $\begin{array}{l}\text { Accepted (Data } \\
\text { Support Model) }\end{array}$ \\
\hline $\begin{array}{l}\text { Work environment has a positive and significant effect } \\
\text { on work motivation }\end{array}$ & 0,264 & 0,099 & 2,923 & 0,003 & $\begin{array}{l}\text { Accepted (Data } \\
\text { Support Model) }\end{array}$ \\
\hline $\begin{array}{l}\text { Career development has a positive and significant } \\
\text { effect on work motivation }\end{array}$ & 0,262 & 0,090 & 2,999 & 0,003 & $\begin{array}{l}\text { Accepted (Data } \\
\text { Support Model) }\end{array}$ \\
\hline
\end{tabular}




\begin{tabular}{lcccccc}
\hline $\begin{array}{l}\text { Empowerment has a positive and significant effect on } \\
\text { the performance of employees }\end{array}$ & 0,284 & 0,094 & 3,305 & 0,001 & $\begin{array}{l}\text { Accepted (Data } \\
\text { Support Model) }\end{array}$ \\
\hline $\begin{array}{l}\text { Work environment has a positive and significant effect } \\
\text { on the performance of employees }\end{array}$ & 0,210 & 0,090 & 2,068 & 0,039 & $\begin{array}{l}\text { Accepted (Data } \\
\text { Support Model) }\end{array}$ \\
\hline $\begin{array}{l}\text { Career development has a positive and significant } \\
\text { effect on the performance of employees }\end{array}$ & 0,221 & 0,082 & 2,448 & 0,014 & $\begin{array}{l}\text { Accepted (Data } \\
\text { Support Model) }\end{array}$ \\
\hline $\begin{array}{l}\text { Work motivation has a positive and significant effect } \\
\text { on the performance of the employee }\end{array}$ & 0,214 & 0,090 & 2,304 & 0,021 & $\begin{array}{l}\text { Accepted (Data } \\
\text { Support Model) }\end{array}$ \\
\hline $\begin{array}{l}\text { Work Motivation fully mediates between } \\
\text { Empowerment and Employee Performance }\end{array}$ & 0,057 & 0,032 & 1,749 & 0,080 & $\begin{array}{l}\text { Accepted (Data } \\
\text { Support Model) }\end{array}$ \\
\hline $\begin{array}{l}\text { Work Motivation fully mediates between the work } \\
\text { environment and employee performance }\end{array}$ & 0,057 & 0,032 & 1,735 & 0,082 & $\begin{array}{l}\text { Accepted (Data } \\
\text { Support Model) }\end{array}$ \\
\hline $\begin{array}{l}\text { Work Motivation fully mediates between career } \\
\text { development and performance of the employee. }\end{array}$ & 0 & 056 & 0 & 056 & $\begin{array}{l}\text { Accepted (Data } \\
\text { Support Model) }\end{array}$ \\
\hline
\end{tabular}

\section{Conclusions}

This study concludes that empowerment has a positive and significant influence on the performance of employees of the Aceh Government Planning Agency, work environment has a positive and significant effect on the performance of the Employees of the Aceh Government Planning Agency, Career Development has a positive and significant effect on the Employee Performance of the Aceh Government Planning Agency, empowerment influences the positive and significant towards the motivation of the employees of the Aceh Government Planning Board, the work environment has a positive and significant impact on the motivation of the employees of the Aceh Government Planning Board, Career Development has a positive and significant influence on the motivation of the employees of the Aceh Government Planning Agency, Motivation has a positive and significant effect on the Employee Performance of the Government Planning Agency Aceh. In addition, Motivation mediates perfectly (full/perfect mediation) towards empowerment, career development, work environment with the performance of employees of the Aceh Government Planning Agency.

\section{References}

Allen, T. D., Day, R., \& Allen, T. D. (2016). The relationship between career motivation and self-efficacy with protégé career success and self-efficacy with prot e career success. Journal of Vocational Behavior, 64(July), 71-91. https://doi.org/10.1016/S0001-8791(03)00036-8

Armstrong, M. (2016). Armstrong 's Handbook of Management and Leadership for HR.

Ayob, A., Rohaida, S., \& Zainal, M. (2011). The Role of Psychological Empowerment on Employees Creativity: the Development of Conceptual Framework. International Conference on Economics, Business and Management IPEDR, 22, 118-122.

Ayobami, P. (2013). Influence of Extrinsic and Intrinsic Motivation on Employees' Performance. Dept. of Business Administration, 1-14.

Baron, R. M., \& Kenny, D. A. (1986). The Moderator-Mediator Variable Distinction in Social Psychological Research : Conceptual, Strategic, and Statistical Considerations. Journal of Pe nality and Social Psychology, 51(6), 1173-1182.

Bandura, A., (1997). Exercise of personal and collective efficacy in changing societies, in Bandura. A. (Ed.), Work environment in Changing Societies, Cambridge: Cambridge University Press.

Bartram, T., \& Casimir, G. (2006). The relationship between leadership and follower in-role performance and 
satisfaction with the leader. http://doi.org/10.1108/01437730710718218

Casio, Wayne F., (1992). Management Human Resources: Productivity, Quality of Worklife, Profit, Singapore: Mc Graw Hill International Editions.

Chasanah, Nur. (2008). Analisis Pengaruh Empowerment, Lingkungan kerja, Pengembangan Karier terhadap Motivasi dalam meningkatkan kinerja karyawan, studi empiris pada karyawan PT. Mayora, Tbk Regional Jateng dan DIY. Tesis. Universitas Diponegoro, Semarang.

Davis, Keith, and Newstrom, John,W. (2002). Organizational Behavior At Work. 11 edition. New York. Mc Graw Hill

Daily, B. F., Bishop, J. W., \& Massoud, J. A. (2012). The role of training and empowerment in environmental performance A study of the Mexican maquiladora industry. The current issue and full text archive of this journal is available at, 32(5), 631-647. http://doi.org/10.1108/01443571211226524

Dobre, O. (2013). Employee motivation and organizational performance. Economic Research, 5(1), 53-60.

Duclos, A., Carty, M. J., Peix, J., Colin, C., Lipsitz, S. R., \& Voirin, N. (2012). Development of a Charting Method to Monitor the Individual Performance of Surgeons at the Beginning of Their Career. journal.pone, 7(7). http://doi.org/10.1371/journal.pone.0041944

Feist, J. \& Feist, G.J. (2002). Theories of Personality (5 ${ }^{\text {th }}$ ed.). Boston: McGraw Hill.

Ghozali, Imam. (2013). Model Persamaan Struktural Konsep \& Aplikasi dengan Program AMOS 21.0. (Edisi V). Semarang: Badan Penerbit Universitas Diponogoro.

Gibson, James L, John M. Ivancevich dan James H. Donnelly Jr, (2000). Organizations: Behaviour, Structure and Process, Boston: McGraw-Hill Companies, Inc,

Hennessey, H. W., \& Bernardin, H. J. (2003). The relationship between performance appraisal criterion specificity and statistical evidence of discrimination. Human Resource Management, 42(2), 143-158. http://doi.org/10.1002/hrm.10073

Imran, R., Fatima, A., Zaheer, A., Yousaf, I., \& Batool, I. (2012). How to Boost Employee Performance: Investigating the Influence of Transformational Leadership and Work Environment in a Pakistani Perspective. Journal of Scientific Research, 11(10), 1455-1462. http://doi.org/10.5829/idosi.mejsr.2012.11.10.741

Imran, R., Majeed, M., \& Ayub, A. (2015). Impact of Organizational Justice , Job Security and Job satisfaction on Organizational Productivity. Journal of Economics, Business and Management, 3(9), 840-845. http://doi.org/10.7763/JOEBM.2015.V3.295

Jayaweera, T. (2015). Impact of Work Environmental Factors on Job Performance, Mediating Role of Work Motivation: A Study of Hotel Sector in England. International Journal of Business and Management, 10(3), 271-278. http://doi.org/10.5539/ijbm.v10n3p271

Kale, S. S., \& Mazaheri, N. (2014). Natural Resources , Development Strategies , and Lower Caste Empowerment in India' s Mineral Belt : Bihar and Odisha During the 1990s. Springer Science+Business Media New York, 49, 343-369. http://doi.org/10.1007/s12116-014-9162-2

Kariuki, A., \& Murimi, C. (2015). Employee Empowerment and Organization Performance of Tata. European Journal of Business and Management, 7(8), 190-201.

Kusworo, Armanu, Rahayu, S. (2015). Influence of Motivation, Organizational Culture and Working Environment With Organizational Commitment As Mediator To Educator Performance. The International Journal of Social Sciences, 35(1), 1-15.

London, M. (1993). Relationships Between Career Motivation, Empowerment and Support. Joiirnal of Ocriipatiotial arid Organizational Psychology (1 993), 66, 5 5-63 Printed in Great Britain, (1 993). 
Luthans, F. (2012). Organizational behavior an evidence-based approach 12th edition. Organizational behavior: an edivence-based approach.

Lee, C. \& Bobko, P. (1994). Work environment belief: comparation of measure. Journal of Applied Psychology, 79 (4): 506-517.

Luthans, F. (2012). Organizational behavior an evidence-based approach 12th edition. Organizational behavior: an edivence-based approach.

Malik, M. I., Ahmad, A., Gomez, S. F., \& Ali, M. (2011). Full Length Research Paper A study of work environment and employees ' performance in Pakistan. Journal of Business Management, 5(34), 13227-13232. http://doi.org/10.5897/AJBM11.1502

Maslow, A. H. (1998). Motivation.

Matthews, R. A., Matthews, R. A., Diaz, W. M., \& Cole, S. G. (2002). The organizational empowerment scale The organizational empowerment scale. The Emerald Research Register for this journal is available at, 32(3), 297-318. http://doi.org/10.1108/00483480310467624

Meyerson, G., \& Dewettinck, B. (2012). Effect of Empowerment on Employees Performance Advanced Research in Economic and Management Sciences, 2(July), 40-46.

Milkovich, Gorge T, Boudreau. 1997. Human Resource Management, Eighth Edition. Richard D Irwin, a Times Mirror Higher Education Group, Inc. Company.

Mohd, O., Anip, H., Faridatul, W., Wan, A., \& Rashdi, M. (2014). Conducive Business Environment: Local Government Innovative Work Behavior. Available online at www.sciencedirect.com, 129, 214-220. http://doi.org/10.1016/j.sbspro.2014.03.669

Muogbo, U. S. (2013). The Impact of Employee Motivation On Organisational Performance ( A Study Of Some Selected Firms In Anambra State Nigeria ) BY. International Journal of Engineering and Science, 2(1964), 70-80.

Nzuve, S. N. M., \& Bakari, T. H. (2012). The Relationship Between Empowerment and Performance in The City Council of Nairobi. Problems of Management in The 21st Century., 5, 83-98.

Oduma, Caroline and Were, S. (2014). Influence of Career Development on Employee Performance in The Public University, A Case of Kenyatta University. International Journal of Social Sciences Management and Entrepreneurship, 1(August), 1-16.

Prahalad, C. K. (2006). The Fortune at the Bottom of the Pyramid: Eradicating Poverty through Profits, ISBN 0-13187729-1.

Spreitzer, G. M. (1995). An Empirical Test of a Comprehensive Model of Intrapersonal Empowerment in the Workplace 1. American Journal of Community Psycholog, 23(5), 601-629.

Tutar, H., Altinoz, M., \& Cakiroglu, D. (2011). The effects of employee empowerment on achievement motivation and the contextual performance of employees. African Journal of Business Management, 5(15), 6318-6329. https://doi.org/10.5897/AJBM11.085

Yukl, G. (2006). Leadership in Organizations Sixth Edition . New Jersey: Pearson Education, Inc.

Zentis, N. L. R. (2007). The Impact of 360-Degree Feedback on Leadership Development. Dissertation. Capella University. 